УДК 347.9

DOI https://doi.org/10.32849/2663-5313/2020.8.05

\title{
Цагік Колінько,
}

канд. юрид. наук,

доцент кафедри иивільно-правових дисциплін

Дніпропетровського державного університету внутрішніх справ

\section{ПРОБЛЕМИ ДОВЕДЕННЯ МОРАЛЬНОЇ ШКОДИ ЗА ЗАКОНОДАВСТВОМ УКРАЇНИ}

У науковій статті досліджено поняття моральної (немайнової) шкоди. Проведено аналіз критеріїв визначення розміру моральної шкоди та прийнятних доказів. Зазначається, що чинне вітчизняне законодавство не містить чіткого визначення поняття моральної шкоди, оскільки не можуть бути передбачені всі випадки протиправних дій, які можуть завдати моральної (немайнової) шкоди. Ми говоримо про негативні наслідки для внутрішньої, психічної сфери людини, їі почуттів, самопочуття, психічного здоров'я - ие відсутність емочійного благополуччя та/або наявність психічного розладу. Підкреслюється, що найважчим моментом у разі подання позовної заяви про відшкодування моральної (немайнової) шкоди є збір доказів, шо підтверджують факт заподіяння моральної шкоди, та визначення розміру такої шкоди. Позивачу недостатньо в позовній заяві зазначити, що він пережив або зазнає моральних страждань. Цей факт повинен бути підтверджений усіма прийнятними засобами доказування (показаннями, довідками медичних установ, потім письмовими доказами тощо). Викладаючи доводи суду, у кожному випадку слід надати пояснення щодо причинного зв'язку протиправного діяння з фактом заподіяння моральної шкоди. Наголошено, що кожна конкретна справа вимагає об'єктивної оиінки судом всіх обставин, оскільки судовий контроль являє собою одну з істотних гарантій захисту конституиійних прав громадян, тим більше у випадках, коли фактичні обставини справи свідчать про наявність иивільно-правового спору. Мета позивача (його представника) - надати суду матеріал для такої оцінки, тобто доказову базу. Наявність достатньої доказової бази виступатиме запорукою визначення судом справедливого розміру компенсаиії моральної шкоди. Зроблено висновок, що для отримання повної компенсації моральної шкоди необхідно використовувати всі наявні процесуальні можливості, намагатися найбільш повно і точно відобразити причинно-наслідковий зв'язок між порушенням прав людини та моральними стражданнями, які вона зазнала. Не повинно бути сумнівів щодо розміру моральної шкоди, і ще повинно бути підтверджено за допомогою прийнятних засобів доказування.

Ключові слова: моральна шкода, відшкодування, засоби доказування, предмет доказування.

Постановка проблеми. У законодавстві України закріплено норми, які дають право особам на відшкодування моральної шкоди, що в сучасній концепції є невід’ємною частиною захисту прав і свобод людини. Немайнова шкода - страждання, заподіяні людині внаслідок неправомірних дій стосовно неї, повинна бути відшкодована в будь-якому разі, тому що без цієї частини відновлення порушених прав неможливо повною мірою реалізувати принцип справедливості, адже тоді залишається некомпенсованою велика частина того негативу, якого зазнає людина.

Відшкодування моральної шкоди залишається в багатьох випадках недосяжним, оскільки моральна шкода, душевні страждання, можливо, деякою мірою і відображаються у висновках експертиз, але повною мірою відобразитись у них ніколи не зможуть, тому що людські почуття надто суб'єктивні.

Аналіз останніх досліджень і публікацій. Варто зазначити, що дослідженням проблеми відшкодування моральної шкоди займались такі вітчизняні вчені, як С. Рабінович, О. Отраднова, Д. Толкачов, М. Фролов, В. Мармазов, В. Васильєв, Л. Корчемна, В. Чернадчук, В. Паліюк, Р. Стефанчук, О. Грищук, І. Забара, Н. Павловська, О. Крикунов та ін.

Метою даного дослідження є 3'ясування особливостей визначення та доведення моральної шкоди.

Виклад основного матеріалу. Як зазначається в наукових джерелах, проблема визначення розміру моральної шкоди у вітчизняній науковій практиці виникла 3 моменту вступу в силу Закону України «Про внесення змін і доповнень до положень законодавчих актів України, що стосуються захисту честі, гідності та ділової репутації громадян та організацій» від 6 травня 1993 року, коли Цивільний кодекс Української РСР був 
доповнений статтею 440-1 про відшкодування моральної (немайнової) шкоди, адже радянське законодавство не містило ані поняття «моральна шкода», ані механізмів її відшкодування [8, с. 86].

Насамперед слід зазначити, що чинне вітчизняне законодавство не містить чіткого визначення поняття «моральна шкода». Згідно зі ст. 23 ЦК України моральна шкода полягає:

1) у фізичному болю та стражданнях, яких фізична особа зазнала у зв'язку з каліцтвом або іншим ушкодженням здоров'я;

2) у душевних стражданнях, яких фізична особа зазнала у зв'язку з протиправною поведінкою щодо неї самої, членів її сім’ї чи близьких родичів;

3) у душевних стражданнях, яких фізична особа зазнала у зв'язку зі знищенням чи пошкодженням її майна;

4) у приниженні честі та гідності фізичної особи, а також ділової репутації фізичної або юридичної особи.

На думку В. Васильєва, законодавець утримується від визначення поняття «моральна (немайнова) шкода», оскільки таке визначення, щоб охопити всі суттєві ознаки поняття, було б доволі громіздким усі випадки неправомірних дій, якими може бути заподіяна моральна (немайнова) шкода, неможливо передбачити, до того ж моральна (немайнова) шкода може бути завдана й іншими діями, якими порушуються майнові й особисті немайнові права особи [1, с. 12].

Як слушно вказує Д. Толкачов, якщо говорити про процесуальні аспекти розгляду судами загальної юрисдикції справ про відшкодування моральної (немайнової шкоди), то, на відміну від цивільного права, у цивільному процесі термін «немайнова шкода» вже втрачає свій зміст, оскільки у зверненні до суду необхідно зазначити, в якому розмірі має бути відшкодована завдана шкода. Тобто в цьому конкретному випадку проявляється умовність поняття «немайнова шкода», яка може розцінюватися як несумісна з грошовим еквівалентом. Тому, на думку Д. Толкачова, термін «моральна шкода» більш виважений, ніж «немайнова шкода», зокрема, що стосується процесуальних галузей наук та безпосередньо різних видів судочинства [5, с. 106].

О. Отраднова пропонує визначати моральну шкоду як негативні наслідки для внутрішньої, психічної сфери людини, її відчуттів, самопочуття, ментального здоров'я, що полягають у відсутності емоційного благополуччя та/або наявності психічного розладу [2, с. 21].

У постанові № 4 від 31 березня 1995 р. «Про судову практику в справах про відшко- дування моральної (немайнової) шкоди» Пленум Верховного Суду зазначив, що суди в окремих випадках припускаються помилок, неповно з'ясовують наявність підстав для відшкодування моральної шкоди, недостатньо обгрунтовують їі розмір. Тобто сторони в процесі голослівно висували свої вимоги, а реальних доказів, які б обгрунтовували їхні вимоги, не надавали [10].

O. I. Сліпченко зазначає, що у даних категоріях справ загальний предмет доказування включає необхідність встановлення таких умов цивільно-правової відповідальності:

- наявність моральної (немайнової) шкоди в потерпілого;

- протиправність дій особи, яка заподіяла шкоду;

- причинний зв'язок між протиправними діями та заподіяною шкодою;

- вина (у передбачених законом випадках) [4, с. 180].

Термін «страждання» означає, що дії, які заподіяли шкоду, обов’язково повинні відобразитися у свідомості потерпілої особи й викликати в неї певну психічну реакцію. Страждання важко оцінити за допомогою будь-якої методики, оскільки вони взагалі не піддаються оцінці, а втрати немайнового характеру можна визначити. Страждання викликають певні зміни в житті особи: неможливість реалізації своїх звичок і бажань, збентеженість, страх, переживання, хвилювання, емоційну нестабільність, прояви депресії, зміни артеріального тиску й виникнення інших хвороб, погіршення стосунків у колективі, у сім'ї, втрату роботи, неможливість зробити кар'єру, втрату довіри близьких людей тощо, іншими словами, зменшення, знищення певного особистого немайнового блага [1, с. 12].

С. I. Шимон вказує, що для визначення глибини фізичних та душевних страждань мають значення такі критерії:

- характер страждання (прості переживання; душевні страждання, страждання, пов'язані з фізичним болем);

- тяжкість ушкодження здоров'я (легке, середньої тяжкості, тяжке);

- вид душевних страждань (занепокоєння, нервозність, сором, приниження, страх, відчай);

- глибина страждань (незначний фізичний або душевний біль, значний біль, сильний біль, нестерпний біль, біль руйнівної для здоров'я сили) [7, с. 55].

Таким чином, найскладнішим моментом в оформленні позовної заяви про відшкодування моральної (немайнової) шкоди є збір доказів, які доводять факт спричинення моральної шкоди та розмір такої шкоди. 
Формування позивачем доказової бази у разі подання заяви про відшкодування матеріальної шкоди не є складним, оскільки шкода завдається або певним матеріальним об'єктам, які можуть бути оглянуті, оцінені тощо, або ж зазначається обсяг витрат позивача, які можуть бути підтверджені документально. У разі подання позовів про компенсацію моральної (немайнової) шкоди у позивачів виникають складнощі щодо формування доказової бази [9].

Доведення факту завдання моральної шкоди $є$ дуже специфічним, тому позивачу непросто сформувати необхідну доказову базу для підтвердження наявності моральної шкоди та підтвердження причинно-наслідкового зв'язку між діями (бездіяльністю) відповідача та негативними наслідками для позивача у вигляді моральної шкоди.

У більшості позовів про компенсацію моральної (немайнової) шкоди, які надходять до судів, позивачі обмежуються фразою: «Мені завдано моральної шкоди». Однак позивачеві недостатньо заявити у позовній заяві, що він пережив або переживає моральні страждання. Цей факт має бути доведений усіма допустимими засобами доказування (показаннями свідків, довідками із медичних закладів, іншими письмовими доказами тощо) [2, с. 21].

Докази - це будь-які фактичні дані, на підставі яких суд встановлює наявність або відсутність обставин, що обгрунтовують вимоги і заперечення сторін, та інші обставини, що мають значення для правильного вирішення справи.

Ці дані встановлюються такими засобами: поясненнями сторін, третіх осіб, їхніх представників, допитаних як свідків; показаннями свідків, письмовими доказами, речовими доказами, зокрема звуко- і відеозаписами, висновками експертів.

Пояснення сторін і третіх осіб надаються сторонами в цивільному процесі й фіксуються у протоколі судового засідання, а в деяких випадках із застосуванням технічних засобів (у таблиці, що подається нижче, цей вид доказу не розглядатиметься). Сторони, треті особи та їхні представники за їхньою згодою можуть бути допитані як свідки про відомі їм обставини, що мають значення для справи.

Показання свідків - це повідомлення про відомі йому обставини, які мають значення для справи. Не є доказом показання свідка, який не може назвати джерела своєї обізнаності щодо певної обставини. У справах про компенсацію моральної шкоди цей вид доказів є найбільш поширеним. Адже зміну психологічного стану позивача у зв'язку
3 негативними емоційно-вольовими переживаннями можуть помітити тільки особи, які мають можливість порівняти стан позивача до події, яка спричинила переживання, та після такої події. Зважаючи на те, що явка у судовий процес $є$ для громадян неабияким психологічним випробовуванням, позивач пропонує до виклику тих осіб, які вже надали йому теоретичну згоду на виклик їх у якості свідків. Однак дійсно корисними для з'ясування обсягів спричиненої моральної шкоди є показання «незалежних» свідків осіб, які спостерігали за позивачем «збоку» (наприклад, колеги по роботі, з якими позивач не підтримує тісних дружніх стосунків), або осіб, які ставляться до позивача «вимушено терпляче» (як правило, це особи, які підтримують стосунки з позивачем в силу незалежних від них обставин (наприклад, родичі одного 3 подружжя). На жаль, суди здебільшого не вживають належних заходів для залучення таких свідків.

Письмові докази - це будь-які документи, акти, довідки, листування службового або особистого характеру або витяги 3 них, що містять відомості про обставини, які мають значення для справи. Письмові докази у справах про компенсацію моральної шкоди, як правило, підтверджують наявність негативних наслідків, які виникли у зв'язку 3 перенесеними емоційно-вольовими переживаннями. Це може бути витяг з історії хвороби, лікарняний листок, письмовий висновок психолога тощо, але щодо того, у який час ці переживання мали місце, що стало їхньою причиною, до чого вони призвели, якої вони були глибини (знову нагадаю про суб'єктивність людського переживання).

Речові докази - це предмети матеріального світу, що містять інформацію про обставини, які мають значення для справи. Речові докази у справах про компенсацію моральної шкоди не є дуже поширеним видом доказів. Як речовий доказ може бути подано, наприклад, друкований засіб масової інформації, у якому оприлюднені відомості, що не відповідають дійсності; аудіо- або відеокасети, які містять відповідний аудіо- або відеопродукт з неправдивою інформацією. Найбільш поширене подання таких речових доказів, як фотографії (негативи); як правило, речові докази фігурують у справах, за якими відповідачами є засоби масової інформації.

Висновки експертів - це докладний опис проведених експертом досліджень, зроблені у їх результаті висновки та обгрунтовані відповіді на питання, задані судом. Для встановлення наявності емоційних страждань можливе використання досвіду, накопиче- 
ного у психології, зокрема застосовування розроблених i впроваджених в практику комплексних методів психологічного консультування у формі психодіагностики (у тому числі і комп'ютерної) і надання різнобічної психологічної допомоги. Звертання до психологічних методик - це не тільки доцільно, але й розумно. Насправді тільки експерт-психолог може встановити наявність або відсутність ознак заподіяння особі моральної шкоди.

Досить поширеним доказом у справах про компенсацію моральної шкоди $є$ висновки експертів-медиків (крім психологів) щодо стану здоров'я позивача і зумовленості негативних емоційно-вольових переживань погіршенням стану здоров'я.

Обгрунтовуючи думку щодо доцільності обов'язкового проведення судово-психологічної експертизи у справах про відшкодування моральної (немайнової) шкоди, що дозволить суду визначити адекватний розмір компенсації такої шкоди залежно від характеру завданих потерпілому фізичних та моральних страждань, Д. Толкачов наголошує на сутності судово-психологічної експертизи та висновку експерта як одного із засобів доказування у даній категорії справ. Так, науковець підкреслює, що предметом такої експертизи є питання про особливості психіки людини, іiї реагування на екстремальні ситуації. На розгляд судово-психологічної експертизи може бути винесено питання: яким $є$ можливий вплив тих чи інших негативних емоцій (душевних переживань), що виникли у досліджуваної особи до події, на характер ії̈ дії та стан такої особи в екстремальних умовах, проте дана експертиза не здатна дати категоричну відповідь, оскільки висновки експерта-психолога про можливість настання якоїсь події чи перебігу певного процесу слід розглядати як ймовірні [5, с. 115].

Вище подано приблизний перелік доказів, якими можна підтвердити наявність моральної шкоди (факти, наявність подій, ставлення осіб, тобто все те, що спричинюе негативні емоційно-вольові переживання позивача) При доведенні до відома суду доказів у кожному випадку треба надавати пояснення щодо причинно-наслідкового зв'язку 3 фактом заподіяння моральної шкоди.

Кожна конкретна справа вимагає об'єктивної оцінки судом всіх обставин, оскільки судовий контроль являє собою одну з істотних гарантій захисту конституційних прав громадян, тим більше у випадках, коли фактичні обставини справи свідчать про наявність цивільно-правового спору. Мета позивача (його представника) - надати суду матеріал для такої оцінки, тобто доказову базу. Наявність достатньої доказової бази виступатиме запорукою визначення судом справедливого розміру компенсації моральної шкоди.

\section{Висновки}

Узагальнюючи викладене, можемо підсумувати, що для отримання відшкодування моральної шкоди у повному обсязі необхідно використовувати всі наявні процесуальні можливості, намагатись найбільш повно і точно відобразити причинний зв'язок між порушенням прав особи і моральними стражданнями, яких вона зазнала. Не повинно виникати сумнівів щодо обсягів немайнової шкоди, і це слід підтвердити за допомогою допустимих засобів доказування.

\section{Список використаних джерел:}

1. Васильєв В. Окремі питання визначення поняття моральної (немайнової) шкоди. Науковий вісник Ужгородського начіонального університету. Серія «Право». 2015. Вип. 32. С. 10-15.

2. Отраднова О. Компенсація моральної шкоди, заподіяної порушенням цивільно-правового договору. Вісник Національної Академії прокуратури України. 2015. № 2. С. 18-23.

3. Про судову практику в справах про відшкодування моральної (немайнової) шкоди: Постанова Пленуму Верховного Суду України від 31 березня 1995 № 4. URL : http://zakon4.rada.gov.ua/ laws/ show/v0004700-95 (дата звернення: 12.07.2020).

4. Сліпченко O.I. Докази та доказування в справах про відшкодування моральної (немайнової) шкоди : автореф. канд. ... юрид. наук: 12.00.03. Харків, 2011. С. 3-4.

5. Толкачов Д.І. Діяльність адвоката у справах про відшкодування моральної (немайнової) шкоди: матеріальні та процесуальні аспекти. Вісник Вищої Ради юстииї. 2011. № 2. С. 103-117.

6. Цивільний Кодекс України від 16 січня 2003 p. URL : http://zakon4.rada.gov.ua/laws/ show/435-15 (дата звернення: 12.07.2020).

7. Цивільний процес України: академічний курс : підручник для студ. юрид. спец. вищ. навч. закл. / ред. С.Я. Фурси. Київ: Видавець Фурса С. Я.: КНТ, 2009. 848 с.

8. Шеремет Т.В., Чайка Т.С. Проблемні практичні та теоретичні аспекти відшкодування моральної шкоди згідно із законодавством України. Юридичний науковий електронний журнал. 2019. № 3. C. 85-89.

9. Маріц Д.О. Відшкодування моральної шкоди у договорах обов'язкового страхування цивільно-правової відповідальності власників наземних транспортних засобів. URL: http:// www.justinian.com.ua/article.php?id=258 (дата звернення: 12.07.2020).

10. URL: http://www.yur-gazeta.com/oarticle/ 920/ (дата звернення: 12.07.2020). 
Tsahik Kolinko. Problems of proving moral harm under the legislation of Ukraine

The scientific article explores the concept of moral (non-property) harm. The analysis of the criteria for determining the amount of non-pecuniary damage and acceptable means of proof. It is noted that the current domestic legislation does not contain a clear definition of the concept of moral harm, since all cases of unlaweful actions that can cause moral (non-property) harm cannot be foreseen. We are talking about negative consequences for the inner, mental sphere of a person, his feelings, well-being, mental health, are the lack of emotional well-being and / or the presence of mental disorder. It is emphasized that the most difficult moment when filing a statement of claim for compensation for moral (non-property) harm is the collection of evidence proving the fact of causing moral harm and the amount of such damage. it is not enough for the plaintiff to state in the statement of claim that he has experienced or is experiencing moral suffering. This fact must be communicated by all acceptable means of proof (testimony, certificates from medical institutions, then written evidence, etc.). When bringing evidence to the court in each case, it is necessary to provide explanations about the causal connection with the fact of causing moral harm. It is emphasized that each particular case requires an objective assessment by the court of all the circumstances, since judicial control is one of the essential guarantees for the protection of the constitutional rights of citizens, especially in cases where the factual circumstances of the case indicate the existence of a civil dispute. The purpose of the claimant (his representative) is to provide the court with material for such assessment, that is, the evidence base. The availability of sufficient evidence will serve as a guarantee for the court to determine the fair amount of non-pecuniary damage. It is concluded that in order to receive full compensation for non-pecuniary damage, it is necessary to use all available procedural possibilities, to try to most fully and accurately reflect the causal link between the violation of human rights and the moral suffering that she suffered. There should be no doubt as to the extent of non-pecuniary damage, and this should be confirmed with the help of acceptable means of proof.

Key words: moral harm, compensation, means of proof, subject of proof. 